\title{
PERANCANGAN ULANG PERALATAN PNEUMATIK BERBASIS PROGRAMMABLE LOGIC CONTROL (PLC) UNTUK KEGIATAN PRAKTIKUM
}

\author{
Ahmad Syahril ${ }^{[1]}$, M. Fajri Hidayat ${ }^{[2]}$ \\ Program Studi Teknik Mesin, Fakultas Teknik \\ Universitas 17 Agustus 1945 Jakarta \\ Jl. Sunter Permai Raya, Sunter Agung Podomoro Jakarta Utara 14350 \\ e-mail: syahrildsm@gmail.com ${ }^{[1]}$, fajri17845@gmail.com ${ }^{[2]}$
}

\begin{abstract}
ABSTRAK
Sebuah kegiatan praktikum sangatlah dibutuhkan dalam dunia pendidikan dimana didasari perlunya saling menghubungkan antara teori-teori dan praktik. Seperti pada bidang keteknikan pasti adanya mesinmesin dan peralatan lainnya untuk digunakan dalam kegiatan praktikum. Pada sebuah labolatorium teknik adanya sebuah mesin peralatan pneumatik semi elektrik yang berbasis Programmable Logic Controller (PLC) yang tidak berfungsi mungkin karena rusak atau kurang adanya faktor pendukung pendukung lainnya.Supaya peralatan tersebut dapat berfungsi kembali harus adanya proses perbaikkan dan perancangan ulang. Untuk cara atau metode perancangan ulang peralatan tersebut ialah mengamati setiap komponen sistem pneumatik apakah ada komponen yang dibutuhkan atau yang harus diganti, mengamati mesin jenis mesin PLC yang digunakan, penambahan sebuah software PLC untuk mengolah data perintah pada PLC yaitu menggunakan software $C x$ Programmer.Setelah dilakukannya proses perhitungan pada sistem pneumatik didapatkan hasil untuk kebutuhan udara silinder kerja ganda geser / lodress cylinder (Q) sebesar 0,129 //min, sedangkan untuk kebutuhan udara silinder kerja ganda geser / Dual-Rod Cylinders (Q) sebesar 1,9 x 10-4 $\ell / \mathrm{min}$.
\end{abstract}

Kata kunci : Sistem Pneumatik, Programmable Logic Controller (PLC), Sofware Cx-Programmer.

\section{PENDAHULUAN}

Otomasi di dunia industri sangatlah bersaing seperti pada sistem pneumatik sudah banyak mengeluarkan pengaplikasian yang sangat bermanfaat sepeti pada industri pengolahan pangan, industri otomotif, industri kimia farmasi, dan industri lainnya. Untuk itu sistem pneumatik ini harus di pelajari lebih mendasar khususnya bagi siswa/mahasiswa di bidang akademik teknik mesin. Sistem pneumatik ini di dalam dunia pendidikan banyak sekali metode pembelajarannya terlebih dalam kegiatan praktikum. Sebuah kegiatan praktikum sangatlah dibutuhkan dalam dunia pendidikan dimana didasari perlunya saling menghubungkan antara teori-teori dan praktik. Seperti pada bidang keteknikan pasti adanya mesin-mesin dan peralatan lainnya untuk digunakan dalam kegiatan praktikum. Berkembangnya teknologi sistem pneumatik melalui otomisasi yaitu sebuah sofware dimana sebagai pengontrol otomatis yang di namakan dengan Programmable Logic Control (PLC). Sistem peneumatik dengan dibarengi suatu sofware PLC diharapkan untuk mengetahui dasar-dasar dan peralatan pneumatik dan bagaimana membuat rangkaian sistem pneumatik yang diaplikasikan ke PLC, lalu lebih memahami bagaimana sebuah sofware PLC bekerja pada rangkaian sistem pneumatik yang sudah di buat dan bisa bekerja dengan sistem PLC. Penulis ingin supaya seluruh pelajar tidak hanya mengerti dari segi materi-materi yang di pelajari tetapi juga memahami secara langsung proses bekerjanya suatu sistem melalui kegiatan praktikum.

\section{DASAR TEORI}

\section{A. Sistem pneumatik}

Pneumatik berasal dari bahasa yunani yaitu pneuma yang artinya udara atau angin. Sistem penumatik merupakan semua sistem yang menggunakan tenaga yang disimpan dalam bentuk udara yang dimampatkan untuk menghasilkan suatu kerja. Sistem penumatik pada penerapannya banyak digunakan untuk sistem otomasi di industri modern, mulai dari proses pencetakan, pengaturan arah benda kerja, 
penyusunan, pencengkraman, pemindahan, samapai penyetoran barang. Untuk sitem kerjanya sendiri sistem pneumatik berasal dari sumber energi sistem kontrol listrik yaitu tenaga listrik yang diperoleh dari catu daya DC bisa 24 Volt atau juaga 12 Volt. Jadi sistem pneumatik menggunakan udara yang bertekanan sebagai sumber energi dan udara yang bertekanan itu dihasilkan oleh sebuah alat yang dinamakan Air Compressor[2].

\section{B. Programmable logic controller (PLC0}

Sistem kontrol PLC ini sebuah prangkat yang dibuat untuk menggantikkan sistem kontrol konvensional. Pada tahun 1986 suatu perusahaan General Motor (GM) meraancang pertama kali sistem PLC dengan gagasan untuk mensubstitusi penggunaan relay-relay dan mengimplementasikan rangkaian sistem kendali.Secara bahasa singkat PLC berarti pengontrol logika yang bisa diprogram. Bisa juga PLC merupakan suatu sistem peralatan yang menggunakan suatu rangkaian logika yang diprogram untuk mengontrol suatu pralatan atau sistem lain. PLC menyerupai komputer elektronik yang mudah digunakan (user friendly) yang memiliki fungsi kendali untuk berbagai tipe dan tingkat kesulitan yang beraneka ragam[2].

\section{B. Parameter antena mikrostrip \\ B.1 Gaya Piston}

Gaya piston yang dihasilkan oleh silinder tergantung pada tekanan udara, diameter silinder dan tahanan gesekan dari komonenperapat. Gaya piston secara teoritis dihitung menurut rumus[6]:

$$
\mathrm{F}=\mathrm{P} \times \mathrm{A}
$$

Untuk silinder kerja tunggal:

$$
\mathrm{F}=\left(D 2 \cdot \frac{\pi}{4} \cdot p\right)-f
$$

Untuk silinder kerja ganda:

1. Lanfkah maju:

$$
\mathrm{F}=\mathrm{D}^{2} \times \frac{\pi}{4} \times \mathrm{p}
$$

2. Langkah mundur:

$$
F=\left(D^{2}-d^{2}\right) \times \frac{\pi}{4} \times p
$$

Keterangan :

$\mathrm{F}=$ Gaya piston $(\mathrm{N})$

$\mathrm{F}=$ Gaya pegas $(\mathrm{N})$

$\mathrm{D}=$ Diameter piston $(\mathrm{m})$

$\mathrm{d}=$ Diameter batang piston $(\mathrm{m})$

$\mathrm{A}=$ Luas penampang piston yang dipakai $\left(\mathrm{m}^{2}\right)$
$\mathrm{P}=$ Tekanan kerja $(\mathrm{Pa})$

Table 1 . Berikut adalah gaya piston dari berbagai ukuran pada tekanan 1 - 10 bar[6]:

\begin{tabular}{|c|c|c|c|c|c|c|c|c|c|c|}
\hline $\begin{array}{c}\text { Diame } \\
\text { ter }\end{array}$ & \multicolumn{10}{|c|}{ Tekanan Kerja (bar) } \\
\hline Piston & $\mathbf{1}$ & $\mathbf{2}$ & $\mathbf{3}$ & $\mathbf{4}$ & $\mathbf{5}$ & $\mathbf{6}$ & $\mathbf{7}$ & $\mathbf{8}$ & $\mathbf{9}$ & $\mathbf{1 0}$ \\
\hline $\mathbf{( m m})$ & \multicolumn{10}{|c|}{ Gaya Piston (kgf) } \\
\hline 6 & 0,2 & 0,4 & 0,6 & 0,8 & 1,0 & 1,2 & 1,4 & 1,6 & 1,8 & 2,0 \\
\hline 12 & 1 & 2 & 3 & 4 & 5 & 6 & 7 & 8 & 9 & 10 \\
\hline 16 & 2 & 4 & 6 & 8 & 10 & 12 & 14 & 16 & 18 & 20 \\
\hline 25 & 4 & 9 & 13 & 17 & 21 & 24 & 30 & 34 & 38 & 42 \\
\hline 35 & 8 & 17 & 26 & 35 & 43 & 52 & 61 & 70 & 78 & 86 \\
\hline 40 & 12 & 24 & 36 & 48 & 60 & 72 & 84 & 96 & 108 & 120 \\
\hline 50 & 17 & 35 & 53 & 71 & 88 & 106 & 124 & 142 & 159 & 176 \\
\hline 70 & 34 & 69 & 104 & 139 & 173 & 208 & 243 & 278 & 312 & 346 \\
\hline 100 & 70 & 141 & 212 & 283 & 353 & 424 & 495 & 566 & 636 & 706 \\
\hline 140 & 138 & 277 & 416 & 555 & 693 & 832 & 971 & 1110 & 1248 & 1386 \\
\hline 200 & 283 & 566 & 850 & 1133 & 1416 & 1700 & 1983 & 2266 & 2550 & 2832 \\
\hline 250 & 433 & 866 & 1300 & 1733 & 2166 & 2600 & 3033 & 3466 & 3800 & 4332 \\
\hline
\end{tabular}

\section{B.2 Kebutuhan udara}

Untuk enyediaan udara dan untuk mengetahui biaya pengadaan energi, terlebih dahulu harus diketahui konsumsi udara pada sistem. Pada tekanan kerja, diameter pistondan langkah tertentu, konsumsi udara dihitung sebagai berikut[6]:

1. Kebutuhan udara = perbandingan kompresi $x$ luas penampang piston $x$ Panjang langkah

\section{Perbandingan kompresi= $\frac{1,031+\text { tekanan kerja (bar) }}{1,031}(6)$}

Table 2. Kebutuhan udara silinder penumatik persentimeter langkah dengan fungsi tekanan kerja dan diameter piston[6].

\begin{tabular}{|c|c|c|c|c|c|c|c|c|c|c|}
\hline Diameter & \multicolumn{10}{|c|}{ Tekanan Kerja (bar) } \\
\hline Piston & $\mathbf{1}$ & $\mathbf{2}$ & $\mathbf{3}$ & $\mathbf{4}$ & $\mathbf{5}$ & $\mathbf{6}$ & $\mathbf{7}$ & $\mathbf{8}$ & $\mathbf{9}$ & $\mathbf{1 0}$ \\
\hline $\mathbf{( m m}$ ) & \multicolumn{8}{|c|}{ Kebutuhan udara (q) dalam liter/cm langkah } \\
\hline 6 & 0,0005 & 0,0008 & 0,0011 & 0,0014 & 0,0016 & 0,0019 & 0,0022 & 0,0025 & 0,0027 & 0,0030 \\
\hline 12 & 0,002 & 0,003 & 0,004 & 0,006 & 0,007 & 0,008 & 0,009 & 0,010 & 0,011 & 0,012 \\
\hline 16 & 0,004 & 0,006 & 0,008 & 0,010 & 0,011 & 0,014 & 0,016 & 0,018 & 0,020 & 0,022 \\
\hline 25 & 0,010 & 0,014 & 0,019 & 0,024 & 0,029 & 0,033 & 0,038 & 0,043 & 0,048 & 0,052 \\
\hline 35 & 0,019 & 0,028 & 0,038 & 0,047 & 0,056 & 0,066 & 0,075 & 0,084 & 0,093 & 0,103 \\
\hline 40 & 0,025 & 0,037 & 0,049 & 0,061 & 0,073 & 0,085 & 0,097 & 0,110 & 0,122 & 0,135 \\
\hline 50 & 0,039 & 0,058 & 0,077 & 0,096 & 0,115 & 0,134 & 0,153 & 0,172 & 0,191 & 0,210 \\
\hline 70 & 0,076 & 0,113 & 0,150 & 0,187 & 0,225 & 0,262 & 0,299 & 0,335 & 0,374 & 0,411 \\
\hline 100 & 0,155 & 0,231 & 0,307 & 0,383 & 0,459 & 0,535 & 0,611 & 0,687 & 0,763 & 0,839 \\
\hline 140 & 0,303 & 0,452 & 0,601 & 0,750 & 0,899 & 1,048 & 1,197 & 1,346 & 1,495 & 1,644 \\
\hline 200 & 0,618 & 0,923 & 1,227 & 1,531 & 1,835 & 2,139 & 2,443 & 2,747 & 3,052 & 3,356 \\
\hline 250 & 0,966 & 1,441 & 1,916 & 2,392 & 2,867 & 3,342 & 3,817 & 4,292 & 4,768 & 5,243 \\
\hline
\end{tabular}

Kebutuhan udara dihitung dengan satuan liter/menit ( $\ell / \mathrm{min})$ sesuai dengan setandar kapasitas kompresor. Kebutuhan udara silinder sebagai berikut[6]:

Untuk silinder kerja tunggal:

$$
\mathrm{Q}=\mathrm{s} \times \mathrm{n} \times \mathrm{q} \text { (dalam } \ell / \mathrm{min})
$$

Untuk silinder kerja ganda:

$$
\mathrm{Q}=2 \text { ( s x n x q ) (dalam } \ell / \mathrm{min})
$$

Keterangan :

$\mathrm{Q}=$ kebutuhan udara silinder 
$\mathrm{q}=$ kebutuhan udara persentimeter langkah piston

$\mathrm{s}=$ panjang langkah piston $(\mathrm{cm})$

$\mathrm{n}=$ jumlah siklus kerja per menit

\section{Desain peralatan}

Perancangan ulang peralatan pneumatic berbasis PLC ini diharapkan dan berfungsi kembali.

\section{C.1 Peralatan programmable logic controller (PLC)}

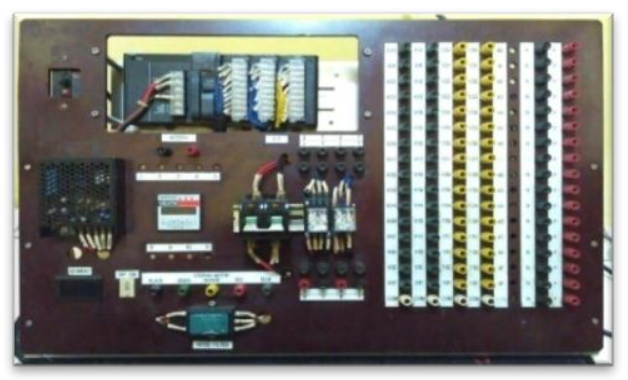

Gambar 1. Rangkaian komponen PLC

\section{C.1.1 Programmable logic control (PLC)}

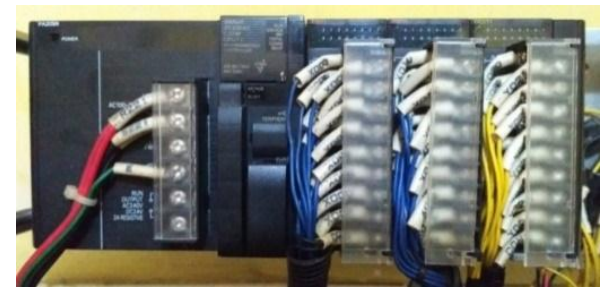

Gambar 2. PLC Omron CJ2M CPU11

Secara umum, PLC memiliki dua fungsi, yakni sebagai kontrol sekuensial dan monitoring plant. Fungsi kontrol sekuensial dapat diartikan sebagai penjagaan agar semua step atau langkah dalam proses sekuensial (pemrosesan input sinyal biner menjadi output) berlangsung dalam urutan yang benar dan tepat.

\section{C.1.2 Power Supply}

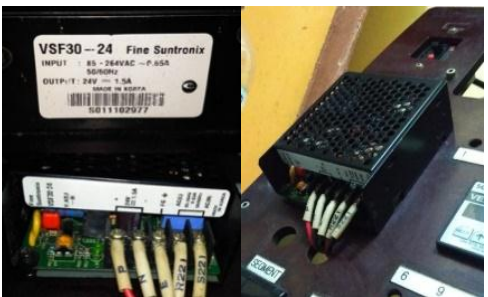

Gambar 3. Fine suntronix VSF30-24 power supply $24 \mathrm{~V} 1,5 \mathrm{~A}$
Berfungsi untuk menyuplai tegangan langsung ke komponen dalam casing yang membutuhkan tegangan.

\section{C.1.3 Pemutus sirkuit}
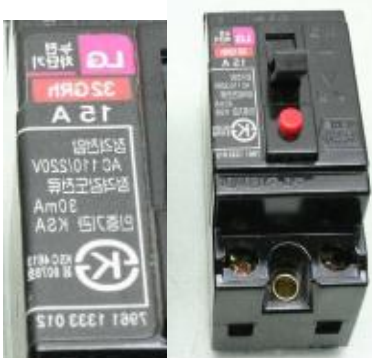

Gambar 4. Pemutus sirkuit LG/LS 32GRh

Alat ini berfungsi untuk memutuskan tegangan AC yang berhubungan dengan tegangan masuk utama daya.

\section{C.4 Konektor}

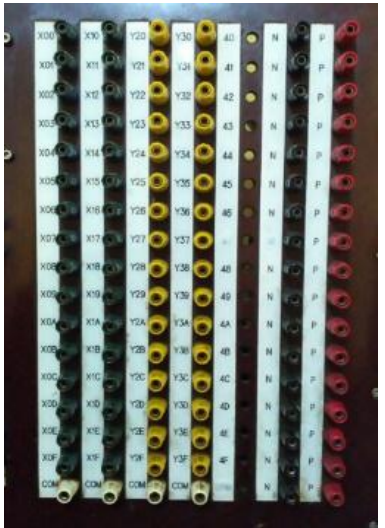

Gambar 5. Terminal soket wire/soket banana

Berfungsi untuk menghubungkan satu rangkaian elektronika ke rangkaian elektronika lainnya ataupun untuk menghubungkan suatu perangkat dengan perangkat lainnya. 


\section{B.1 Peralatan pneumatic}

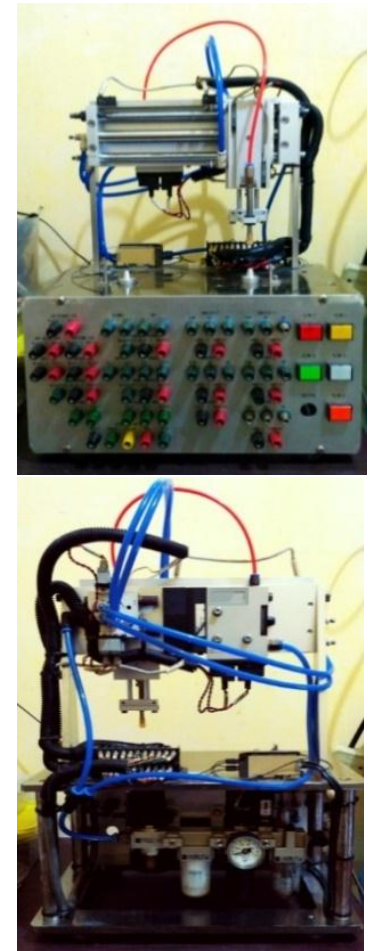

Gambar 6. Peralatan pneumatik

\section{B.1.1 Kompresor}

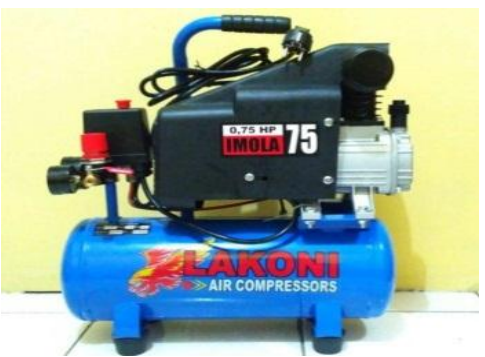

Gambar 7. Kompressor angina 0,75 HP LAKONI - IMOLA 75

Berfungsi untuk meningkatkan tekanan atau memapatkan fluida gas atau udara yang akan didistribusikan untuk suatu rangkaian pneumatik atau komponen alat lainnya.

\section{B.1.2 Katup 3/2 way}

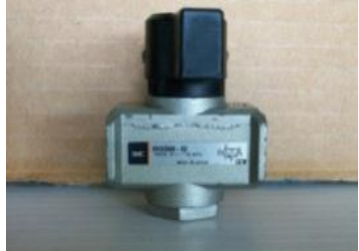

Gambar 8. Katup 3/2 way

Berfungsi untuk melewatkan, menahan, dana tau mengarahkan aliran udara bertekanan.

\section{B.1.3 Filter regulator lubrikator}

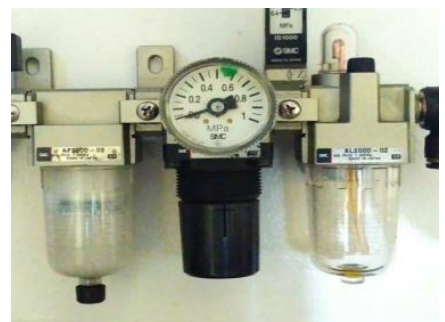

Gambar 9. Filter regulator lubrikator

Filter untuk penyaring udara (angin) agar udara yang masuk pada komponen lanjutan agar tidak tercemar partikel asing yang bisa merusak komponen-komponen yang lain seperti solenoid dan cylinder angin. Regulator atau bisa disebut dengan pengatur untuk mengatur berapa tekanan udara diinginkan dari pengguna, biasanya tekanan yang digunakan sekitar 0,4 Mpa - 0,6 Mpa atau dalam hitung lain 4 Bar - 6 Bar. Lubricator sama juga dengan bagian pelumasan untuk memberikan pelumasan pada bagian - bagian pneumatik yang begerak seperti piston pada solenoid, piston pada cylinder angin..

\section{B.1.4 Sensor fotolistrik}

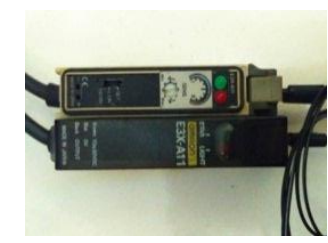

Gambar 10. Sensor fotolistrik E3XA11

Sensor yang bekerja dengan prinsip seperti transistor sebagai saklar. Energi cahaya akan diubah menjadi suatu sinyal listrik. Adanya suatu reflector yang berfungsi untuk memantulkan cahaya yang dipancarkan oleh Photoelectric. 


\section{B.1.4 Reed switch}
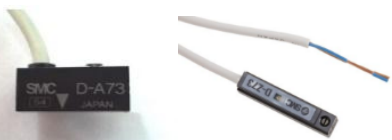

Gambar 11. Reed switch SMC D-Z73 dan SMC D-Z73

Reed Switch adalah sensor yang berfungsi juga sebagai saklar yang aktif atau terhubung apabila di area jangkauan nya terdapat medan magnet.

\section{B.1.5 Rodless cylinder}

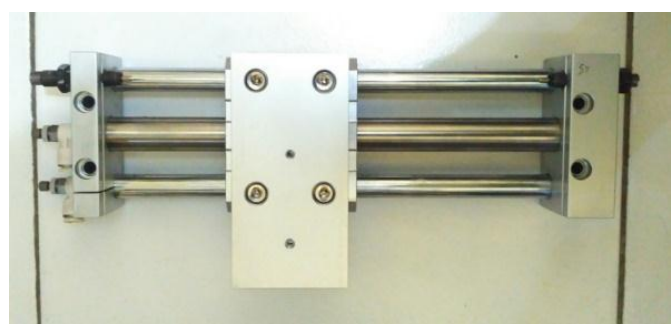

Gambar 12. Rodless cylinder SMC NCDY2S15H-150H

Silinder rodless biasanya berupa silinder yang tidak memiliki batang piston dan berfungsi melakukan gerakan linier. Bisa dikategorikan sebagai drive linier.

\section{B.1.6 Dual-rod cylinder}

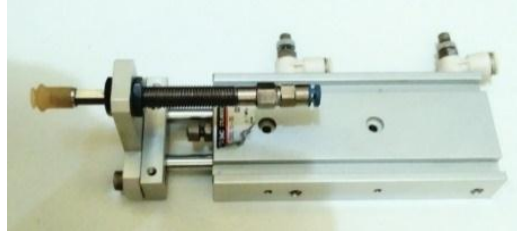

Gambar 13. Dual-rod cylinder SMC pneumatik guided cylinder CXSL10-50-XB9

Sama dengan silinder rodless untuk Dual-Rod silinder juga biasanya berupa silinder yang tidak memiliki batang piston dan berfungsi melakukan gerakan linier.

\section{B.1.7 Katup solenoid udara dengan konektor clip-on}

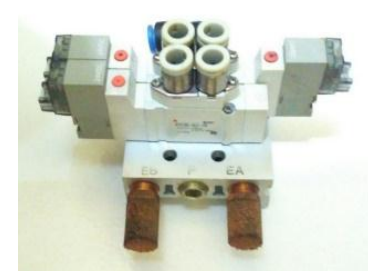

Gambar 14. Katup solenoid udara dengan konektor cli-on SMC SY3220-5 seri LZC6SY3000

Berfungsi untuk menggerakan piston atau tabung cylinder yang dapat digerakan oleh arus AC maupun DC, solenoid valve pneumatic atau katup (valve) solenoida mempunyai lubang keluaran, lubang masukan dan lubang exhaust.

\section{B.1.8 Vacuum ejector}

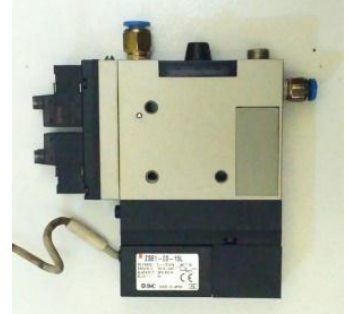

Gambar 15. Vacuum Ejector dengan Valve and Switch SMC ZM131H-K5LZ-E15L-Q

Berfungsi untuk merubah daya tiup menjadi daya hisap atau tiupan kompresor dijadikan hisap atau vacuum.

\section{B.1.9Vertikal Vacuum entry dengan buffer vacuum pad}

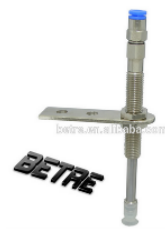

Gambar 16. SMC Vertical Vacuum Masuk Dengan Buffer Vacuum Pad

Berfungsi untuk menghisap suatu benda yang sesuai dengan ukuran pad dan kapasitas hisapnya.

\section{DIAGRAM ALIR PERANCANGAN}

A. Tahapan perancangan

Berikut ialah tahapan untuk perancangan ulang mesin pneumatik yang berbasis PLC aar mesin bisa difungsikan kembali sesuai perancangan awalnya. 


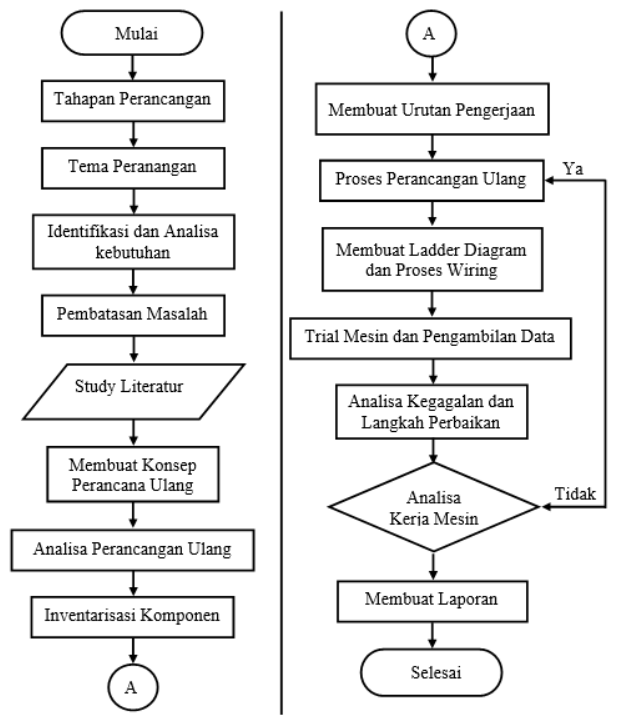

Gambar 17. Diagram alir perancangan

\section{B. Rangkaian peralatan pneumatic dan PLC}

Uuntuk mengiliustrasikan prinsip kerja PLC sederhana dan merupakan menjadi satu perangkat control yang berbasis computer secara sederhana yaitu sebagai berikut:

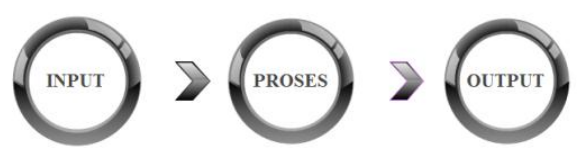

\section{Gambar 18. Prinsip Kerja PLC Secara} Sederhana

Untuk memudahkan dalam mengilustrasikan hubungan antara prangkat komputer dengan prangkat PLC, lalu prangkat PLC dengan sebuah rangkaian pneumatik yang menjadi satu rangkaian keseluruhan. Maka dibuat hubungan sebagai berikut:

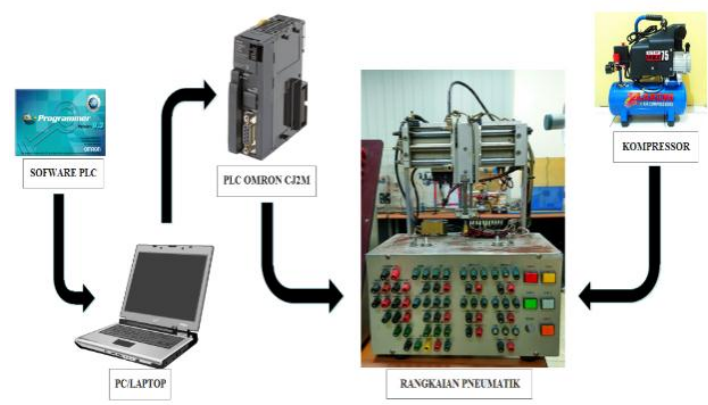

Gambar 19. Hubungan Antara Perangkat Komputer, Prangkat PLC, Dan Rangkaian Pneumatik

\section{Deskripsi Kerja}

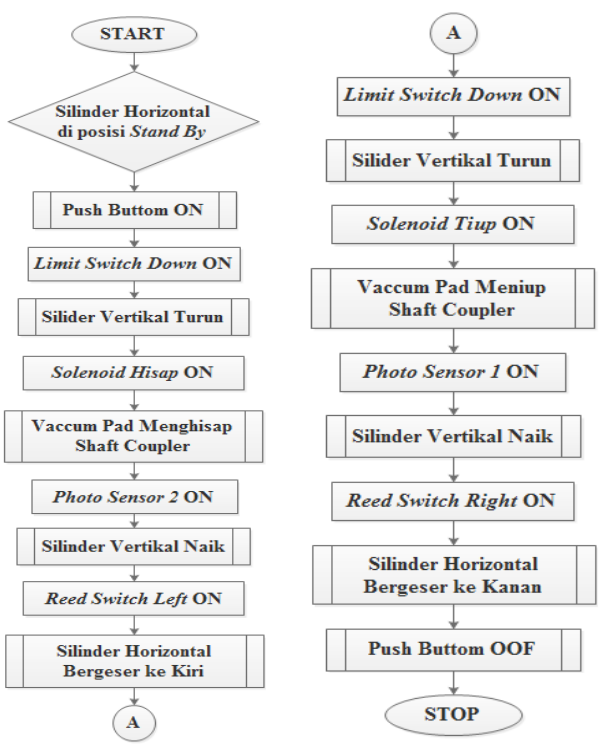

B. Gambar 20. Deskripsi.kerja peralatan

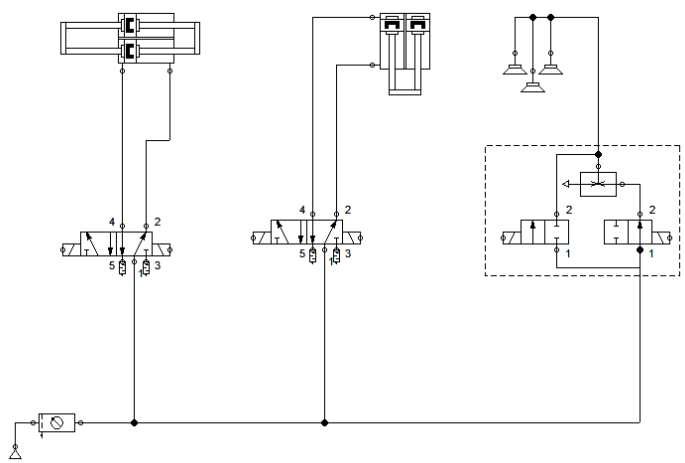

Gambar 21. Diagram pneumatic 
B. Wiring diagram input/output

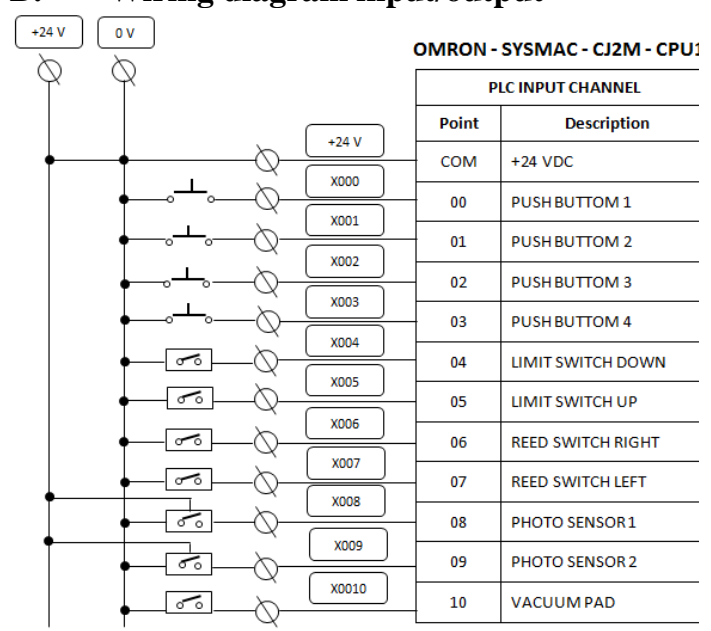

Gambar 22. Wiring diagram input

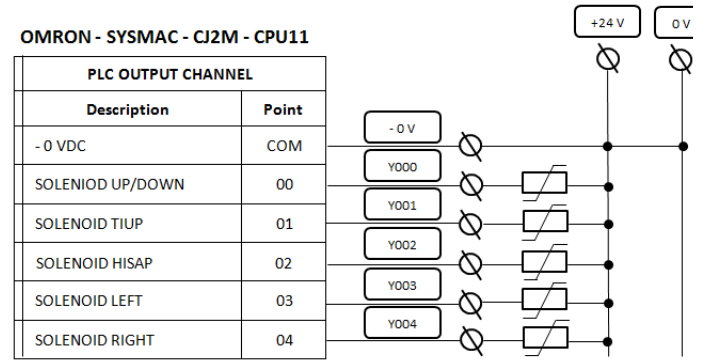

Gambar 23. Wiring diagram output

\section{Diagram ladder peralatan} pneumatik pada software CX-Programmer

\section{C.1 Diagram ladder perintah input}

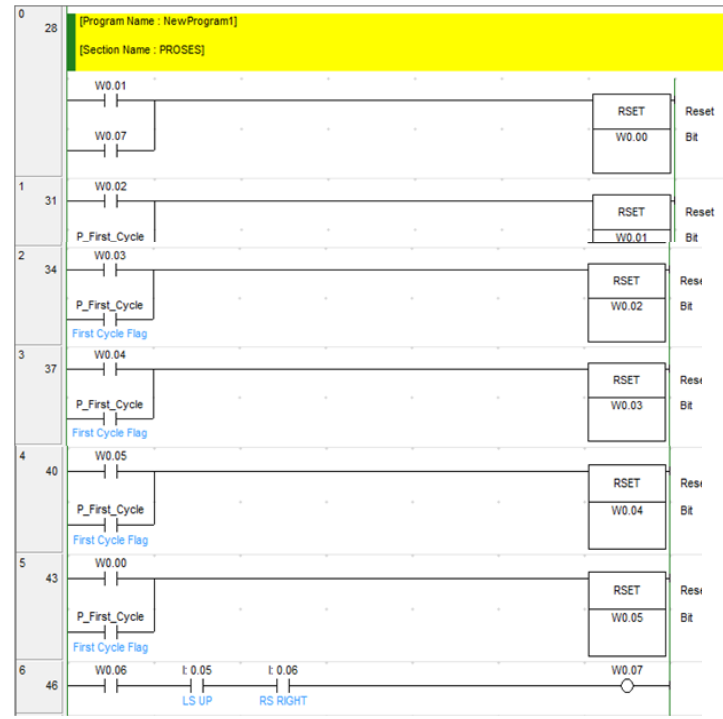

Gambar 24. Diagram ladder perintah input

\section{C.2 Diagram ladder perintah proses}

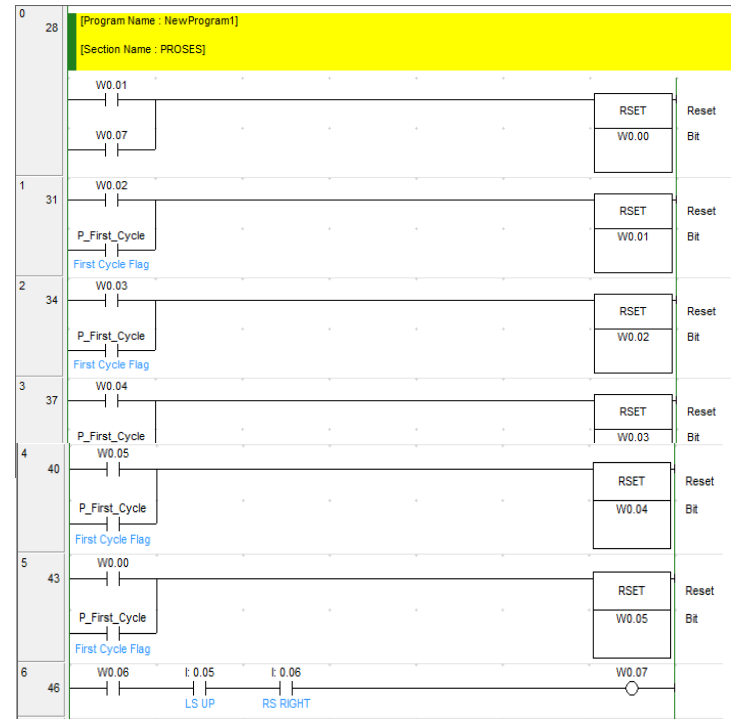

Gambar 25. Diagram ladder perintah proses

\section{C.3 Diagram ladder perintah output}

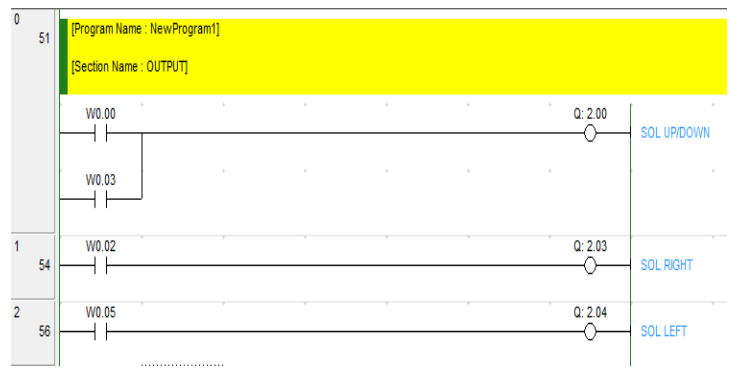

Gambar 26. Diagram ladder perintah output

\section{PERHITUNGAN}

A. Variabel yang diperlukan dalam perhitungan

Untuk menentukan kerja sistem diperlukan data pendukung yang telah diketahui, berikut ini adalah data-data teknik yang telah diketahui:

\section{A.1 Silinder Geser / Lodress Cylinder}

- Merek $=$ SMC

- Tipe $=$ NCDY2S15H-150B

- Jenis gerakan $=$ Double Acting

- Diameter dalam (D) $=15 \mathrm{~mm}=0,015$ $\mathrm{m}$

- Langkah kerja $(\mathrm{L})=247 \mathrm{~mm}=0,247$ $\mathrm{m}$

A.2 Silinder Geser / Dual-Rod Cylinders

- Merek $=$ SMC

- Tipe = CXSL10-50-XB9 
- Jenis gerakan $=$ Double Acting

- Diameter dalam (D) $=10 \mathrm{~mm}=0,01$ $\mathrm{m}$

- Langkah kerja $(\mathrm{L})=60 \mathrm{~mm}=0,06 \mathrm{~m}$

B. Perhitungan silinder geser/lodress cylinder

\section{Luas Permukaan Silinder}

$\mathrm{A}=\frac{\pi}{4} \mathrm{xD}$

Diketahui :

- $\operatorname{diameter}$ dalam $(\mathrm{D})=15 \mathrm{~mm}=0,015$ $\mathrm{m}$

Maka :

$A=\frac{\pi}{4} \times\left(0,015^{2}\right)=0,000176 \mathrm{~m}^{2}$

$=1,76 \times 10^{-4} \mathrm{~m}^{2}$

\section{Perhitungan gaya piston}

$\mathrm{F}=\mathrm{Axp}$.

Diketahui :

- luas permukaan silinder $(\mathrm{A})=1,76 \mathrm{x}$ $10^{-4} \mathrm{~m}^{2}$

- tekanan udara kompresi (p) $=3 \times 10^{5}$ $\left(\mathrm{N} / \mathrm{m}^{2}\right)$

Maka :

$$
\begin{array}{r}
\mathrm{F}=1,76 \times 10^{-4} \times 3.10^{5}=0,050 \mathrm{~N} \\
=5,0 \times 10^{-2} \mathrm{~N}
\end{array}
$$

\section{Silinder kerja ganda}

a. Langkah Maju

$\mathrm{F}=\mathrm{D}^{2} \mathrm{x}-\frac{\pi}{4} \mathrm{xp}$

Dimana :

- $\operatorname{diameter}$ dalam $(\mathrm{D})=15 \mathrm{~mm}=0,015$ $\mathrm{m}$

- tekanan udara kompresi $(\mathrm{p})=3 \cdot 10^{5}$ $(\mathrm{N} / \mathrm{m} 2)$

Maka :

$$
\begin{aligned}
\mathrm{F}=\left(0,015^{2}\right) \times \frac{\pi}{4} \times 3 & .10^{5}=0,055 \mathrm{~N} \\
= & 52,98 \mathrm{~N}
\end{aligned}
$$

\section{b. Langkah Mundur}

$F=\left(D^{2}-d^{2}\right) x \frac{\pi}{4} x p$

Diketahui :

- $\operatorname{diameter}$ dalam $(\mathrm{D})=15 \mathrm{~mm}=0,015$ $\mathrm{m}$
- diameter batang piston $(\mathrm{d})=10 \mathrm{~mm}=$ $0,01 \mathrm{~m}$

- tekanan udara kompresi $(\mathrm{p})=3 \cdot 10^{5}$ $\left(\mathrm{N} / \mathrm{m}^{2}\right)$

Maka :

$F=(0,0152-0,012) \times \frac{\pi}{4} \times 3 \cdot 10^{5}=29,43$ $\mathrm{N}$

\section{Kebutuhan Udara}

a. Silinder kerja ganda

$\mathrm{Q}=2 \times(\mathrm{s} \times \mathrm{n} \times \mathrm{q})($ dalamliter $/ \mathrm{min})$.

Diketahui :

- kebutuhan udara persentimeter langkah piston $($ Tabel $)(\mathrm{q})=0,008$ liter/cm

- panjang langkah piston $(\mathrm{s})=167 \mathrm{~mm}$ $=16,7 \mathrm{~cm}$

- jumlah siklus kerja per menit $(n)= \pm$ 29,1 detik $=0,486$ menit

Maka :

$\mathrm{Q}=2 \times(16,7 \times 0,486 \times 0,008)=0,129$

Liter/menit

5. Konsumsi udara dihitung sebagai berikut:

a. Perbandingan kompresi= $\underline{1,031 \times \text { Tekanan kerja (bar) }}$

Diketahui :

- Tekanan kerja (bar) $=3.10^{5} \mathrm{~N} / \mathrm{m}^{2}$

Maka :

Perbandingan kompresi $=\frac{1,031 \times 3 \times 105}{1,031}$

$$
=3.10^{5} \mathrm{~N} / \mathrm{m}^{2}
$$

b. Kebutuhan Udara = perbandingan kompresi $x$ luas penampang piston $x$ panjang langkah

Diketahui :

- Perbandingan kompresi $=3.10^{5} \mathrm{~N} / \mathrm{m}^{2}$

- Luas penampang $(\mathrm{A})=1,76 \times 10^{-4} \mathrm{~m}^{2}$

- Panjang langkah (s) = $167 \mathrm{~mm}=0,167$ $\mathrm{m}$

Maka :

$Q=3 \times 10^{5} \mathrm{~N} / \mathrm{m}^{2} \times 1,76 \times 10^{-4} \mathrm{~m}^{2} \times 0,167 \mathrm{~m}$

$=8,817 \mathrm{~N} / \mathrm{m}^{3}$

$=881,7 \mathrm{~N} / \mathrm{cm}^{3}$

B. Perhitungan silinder geser/lodress cylinder 


\section{Luas Permukaan Silinder}

$\mathrm{A}=\frac{\pi}{4} \mathrm{xD}$

Diketahui :

-diameter dalam $(\mathrm{D})=10 \mathrm{~mm}=0,01 \mathrm{~m}$

Maka :

$\mathrm{A}=\frac{\pi}{4} \times\left(0,01^{2}\right)=0,0000785 \mathrm{~m}^{2}$

$$
=7,85 \times 10^{-5} \mathrm{~m}^{2}
$$

\section{Perhitungan gaya piston}

$\mathrm{F}=$ Axp

Diketahui :

- luas permukaan silinder $(\mathrm{A})=7,85 \times 10^{-5}$ $\mathrm{m}^{2}$

- tekanan udara kompresi $(\mathrm{p})=3 \cdot 10^{5}$ $\left(\mathrm{N} / \mathrm{m}^{2}\right)$

Maka :

$\mathrm{F}=7,85 \times 10^{-5} \times 3.10^{5}=23,55 \mathrm{~N}$

\section{Silinder kerja ganda}

\section{a. Langkah Maju}

$\mathrm{F}=\mathrm{D}^{2} \mathrm{x}-\frac{\pi}{4} \mathrm{xp}$

Dimana :

- diameter dalam $(\mathrm{D})=10 \mathrm{~mm}=0,01 \mathrm{~m}$

- tekanan udara kompresi $(\mathrm{p})=3 \cdot 10^{5}$ $(\mathrm{N} / \mathrm{m} 2)$

Maka :

$\mathrm{F}=\left(0,01^{2}\right) \times \frac{\pi}{4} \times 3.10^{5}=23,55 \mathrm{~N}$

\section{b. Langkah Mundur}

$F=\left(D^{2}-d^{2}\right) x \frac{\pi}{4} x p$

Diketahui :

- diameter dalam $(\mathrm{D})=10 \mathrm{~mm}=0,01 \mathrm{~m}$

- diameter batang piston $(\mathrm{d})=8 \mathrm{~mm}=$ $0,008 \mathrm{~m}$

- tekanan udara kompresi $(\mathrm{p})=3 \cdot 10^{5}$ $\left(\mathrm{N} / \mathrm{m}^{2}\right)$

Maka :

$F=(0,012-0,0082) \times \frac{\pi}{4} \times 3 \cdot 10^{5}=8,478$ $\mathrm{N}$

\section{Kebutuhan Udara}

\section{a. Silinder kerja ganda}

$\mathbf{Q}=\mathbf{2}(\mathbf{x s x n x q})($ dalamliter $/ \mathrm{min})$.

Diketahui :
- kebutuhan udara persentimeter langkah piston $($ Tabel $)(\mathrm{q})=0,004$ liter/cm

- $\quad$ panjang langkah piston $(\mathrm{s})=50 \mathrm{~mm}$ $=0.05 \mathrm{~cm}$

- $\quad$ jumlah siklus kerja per menit $(n)= \pm$ 29,1 detik $=0,486$ menit

Maka :

$\mathrm{Q}=2 \times(0,05 \times 0,486 \times 0,004)=0,00019$

Liter/menit

$$
=1,9 \times 10^{-4} \text { Liter/menit }
$$

5. Konsumsi udara dihitung sebagai berikut:

a. Perbandingan kompresi = 1,031 x Tekanan kerja (bar) 1,031

Diketahui :

- Tekanan kerja (bar) $=3 \cdot 10^{5} \mathrm{~N} / \mathrm{m}^{2}$

Maka :

b. Perbandingan kompresi $=\frac{1,031 \times 3 \times 105}{1,031}=$ $3.10^{5} \mathrm{~N} / \mathrm{m}^{2}$

Kebutuhan Udara = perbandingan kompresi $x$ luas penampang piston $x$ panjang langkah

Diketahui :

- $\quad$ Perbandingan kompresi $=315 \mathrm{~N} / \mathrm{m}^{2}$

- $\quad$ Luas penampang $(\mathrm{A})=7,85 \times 10^{-5}$ $\mathrm{m}^{2}$

- $\quad$ Panjang langkah $(\mathrm{s})=50 \mathrm{~mm}=0,05$ $\mathrm{m}$

Maka :

Kebutuhan Udara $=3 \times 10^{5} \mathrm{~N} / \mathrm{m}^{2} \times 7,85 \times 10^{-5}$ $\mathrm{m}^{2} \times 0,05 \mathrm{~m}=1.1775 \mathrm{~N} / \mathrm{m}^{3}$

\section{KESIMPULAN}

Pada perancangan ulang peralatan pneumatik yang berbasis PLC untuk kegiatan praktikum ini menggunakan teori dasar perancangan dari buku pengenalan, instalasi, pengaplikasian PLC, serta buku sistem pneumatic pada manufaktur industri dan juga buku dasar perancangan teknik mesin. Teoriteori ini digunakan sebagai dasar dari perancangan ulang peralatan pneumatik berbasis PLC untuk kegiatan praktikum. Dengan menggunakan teori ini pemilihan versi yang terbaik dilakukan, sehingga perancangan ulang akan mendapatkan hasil yang terbaik. Berdasarkan hasil perhitungan pada peralatan pneumatik yang saya pelajari ini menggunakan 2 silinder ganda dengan data sebagai berikut: 
A. Hasil perhitungan pada lodress cylinder

- Luas permukaan silinder $(\mathrm{A})=1,76$ $\mathrm{x} 10^{-4} \mathrm{~m}^{2}$

- Perhitungan gaya pisto $(\mathrm{F})=5,0 \mathrm{x}$ $10^{-2} \mathrm{~N}$

- Silinder kerja ganda
a. $\quad$ Langkah maju $(\mathrm{F})=52,98$ $\mathrm{N}$
b. Langkah mundur (F) = $29,43 \mathrm{~N}$

- Kebutuhan Udara silinder kerja ganda $(Q)=0,129$ Liter/menit

- Kebutuhan udara $=881,7 \mathrm{~N} / \mathrm{cm}^{3}$

B. Hasil perhitungan pada Dual-Rod Cylinders

- $\quad$ Luas permukaan silinder $(A)=7,85$ $\mathrm{x} 10^{-5} \mathrm{~m}^{2}$

- Perhitungan gaya pisto $(\mathrm{F})=23,55 \mathrm{~N}$

- Silinder kerja ganda

a. Langkah maju $(F)=23,55$ $\mathrm{N}$

b. Langkah mundur (F) = $8,478 \mathrm{~N}$

- Kebutuhan Udara silinder kerja ganda $(\mathrm{Q})=1,9 \times 10^{-4} \mathrm{Liter} / \mathrm{menit}$

- Kebutuhan udara $=1,177 \mathrm{~N} / \mathrm{cm}^{3}$

\section{Saran}

Pada perancangan ini tidak pastinya masih sangat adanya banyak kekurangankekurangan. Maka dari itu ingin lebih jauh mempelajari lagi agar bisa mengembangkan ide baru sehingga dapat menyempurnakannya. Dari hasil perancangan ulang ini ada beberapa saran dari kami antara lain:

1. Penambahan modul output pada PLC untuk mengoprasikan peralatan yang belum bisa beroprasi.

2. Perapihan sistem rangkaian yang lebih rapih seperti penambahan panel pengontrol supaya lebih mudah dalam sistem pengontrolan dan pengoprasian.

3. Penambahan tombol emergency stop untuk mematikan mesin apabila mesin terjadi kerusakan, ini dimaksudkan untuk lebih mengefisienkan waktu kerja.

\section{DAFTAR PUSTAKA}

Iwan Setiawan, "Programmable Logic Controller (PLC) dan Teknik Perancangan Sistem Kontrol", Yogyakarta ; Penerbit Andi ; 2005

Hanif Said, "Aplikasi Programmable Logic Control (PLC) dan Sistem Pneumatik pada Manufaktur Industri",Andi, Yogyakarta ; 2013
Hanif Said, "Programmable Logic Controller (PLC) Pengenalan, Instalasi, dan Contoh Aplikasi (untuk Pemula)", Yogyakarta : CV Andi Offset ; 2016

Balza Achmad, "Programmable PLC Menggunakan Simulator" ; Yogyakarta ; CV Andi Offset

Omron, "PLC Basic Training Manual Hand Book", Jakarta ; PT Omron Electronics

ST Nunung Gunung Riyadi, Pneumatik, ATMI Surakarta 